\title{
SEQUENTIAL DETERMINATION OF IRON AND TITANIUM BY FLOW-INJECTION ANALYSIS
}

\author{
M. G. M. Andrade, S. L. C. Ferreira, B. F. Santos and A. C. S. Costa \\ Instituto de Química, Universidade Federal de Bahia Salvador, Bahia 40210, Brazil
}

(Received 8 October 1991. Revised 13 February 1992. Accepted 21 February 1992)

\begin{abstract}
Summary-A flow-injection method has been developed for the sequential spectrophotometric determination of iron and titanium using 3,4 dihydroxybenzoic acid as chromogenic reagent. The system involves the sequential measurement of the absorbances of the complexes at 380 and $570 \mathrm{~nm}$. The system is designed using a simultaneous injection of sample and reagent into separate carrier streams. The proposed method is characterized by a precision of about $2 \%$, a sampling rate of about $\mathbf{5 0}$ samples per hour, and a reagent consumption of $200 \mu \mathrm{l}(0.50 \%$ solution) per sample. It is relatively free of interferences and was used for the sequential determination of titanium and iron in rocks.
\end{abstract}

Flow-injection analysis (FIA) is a rapid and precise technique which has found wide application, especially in agricultural, environmental, geochemical, clinical and pharmaceutical analysis. The reaction between 3,4 dihydroxybenzoic acid (protocatechuic acid) or DHB with iron(III) and titanium(IV) allows the sequential determination of iron and titanium by flow injection, based on the additive property of the absorbances. Iron(III) reacts with this reagent, forming a complex with absorption maxima at 380 and $570 \mathrm{~nm}$, and titanium(IV) forms a complex with an absorption peak at $380 \mathrm{~nm}$. Considering these facts, a method is proposed in which the absorbances are measured at $\mathbf{3 8 0}$ and $570 \mathrm{~nm}$. DHB is a good reagent for flowinjection analysis, because it is soluble in water $(2 \mathrm{~g} / 100 \mathrm{ml})^{1}$ and does not absorb in the visible region of the spectrum. The reaction of iron(III) with DHB was studied by Hsieh and Liang ${ }^{2}$ and of titanium(IV) with DHB by Sommer. ${ }^{3}$ The 3,4 dihydroxybenzoic acid reagent has been used in the flow-injection analysis of manganese ${ }^{4-6}$ and for conventional spectrophotometric determination of molybdenum, ${ }^{7}$ vanadium, ${ }^{8,9}$ cerium $^{10}$ and niobium. ${ }^{11}$

\section{EXPERIMENTAL}

\section{Reagents}

3,4 Dihydroxybenzoic acid solution. A 2.5-8 amount was dissolved in $500 \mathrm{ml}$ of water.

Standard iron(III) solution. Prepared from iron(III) sulfate heptahydrate and standardized gravimetrically.
Standard titanium(IV) solution. ${ }^{12}$ Prepared by dissolving titanium(IV) oxide $(0.20 \mathrm{~g})$ in sulfuric acid $(8 \mathrm{ml})$ and ammonium sulfate $(3.2 \mathrm{~g})$, heating and dilution with distilled water.

Buffer solution ( $p H$ 6.0). Prepared by dissolving $0.31 \mathrm{ml}$ of acetic acid and $12.88 \mathrm{~g}$ of sodium acetate trihydrate in one litre of distilled water.

\section{Apparatus}

A Varian DMS 100 spectrophotometer equipped with an $8-\mu 1$ flow cell, a Fisher $600 \mathrm{pH}$ meter, a Micronal B332 peristaltic pump and an Intralab recorder were used.

\section{Sample preparation}

Weigh $0.2-0.3 \mathrm{~g}$ of dry material $\left(110^{\circ}\right)$, transfer to a Tefion beaker, and add a few mililiters of water so as to form a wet mixture. Add $1 \mathrm{ml}$ of sulphuric acid $(98 \%)$ and $10 \mathrm{ml}$ of hydrofluoric acid (40\%). Heat, on a hot plate, until almost dry.

Add an additional $1 \mathrm{ml}$ of sulphuric acid and $10 \mathrm{ml}$ of hydrofluoric acid and heat until white fumes. Add 5-10 ml of hydrochloric acid (37\%) and transfer the contents of the beaker to a 250-ml glass beaker.

Boil to dissolve completely all the residue, cool to room temperature and transfer, with demineralized water, to a standard flask and dilute to volume.

\section{Flow-injection analysis}

Carrier solution $\mathrm{C}$ (buffer solution pH 6.0) is pumped into the analytical lines at a flowrate of $3.50 \mathrm{ml} / \mathrm{min}$ with a peristaltic pump 


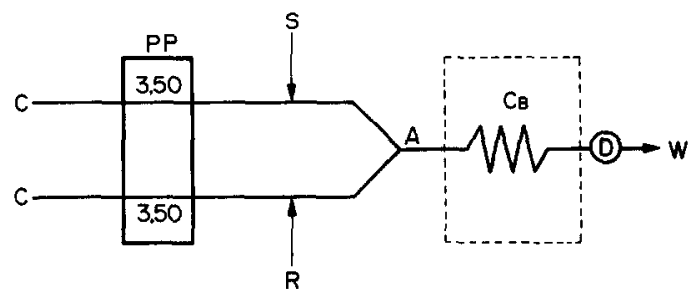

Fig. 1. Flow diagram: $\mathrm{C}$ carrier solution (buffer solution $\mathrm{pH}$ 6.0), PP peristaltic pump, $S$ sample, $R$ chromogenic reagent solution, A confluence point, $\mathrm{CB}$ mixing coil $(0.5 \mathrm{~mm}$ i.d., $100 \mathrm{~cm}$ long), $\mathrm{D}$ detector-equipped with flow cell (volume $8 \mu 1)$, W waste.

[Fig. 1]. The sample solution $S(200 \mu 1)$ and reagent solution $R(200 \mu 1)$ are introduced simultaneously into the carrier streams by a double proportional injector and the absorbance of the complex is monitored in the flow-through cell $D$ at $380 \mathrm{~nm}$ for the titanium(IV)-complex and 380 and $570 \mathrm{~nm}$ for the iron(III)-complex, against the carrier solution as reference (baseline), separate injections are made for measurements at the two wavelengths. A narrow coil $(100 \mathrm{~cm}$ long) is attached before the flow-through cell, as a back-pressure and mixing coil.

For calibration, similarly treated standard solutions are injected between the sample runs. The area or height of the absorbance peak can be used for calibration.

\section{RESULTS AND DISCUSSION}

The iron(III) reacts with DHB in the range pH 5.0-6.0 forming a complex with absorption maxima at 380 and $570 \mathrm{~nm}$ and molar absorptivities of $2.84 \times 10^{3}$ and $4.10 \times 10^{3}$ $1 \cdot \mathrm{mole}^{-1} \cdot \mathrm{cm}^{-1}$, respectively. The titanium forms a complex with $\mathrm{DHB}$ in the $\mathrm{pH}$ range 4.0-6.0, with an absorption maximum at 380 and a molar absorptivity of $1.54 \times 10^{4}$ $1 \cdot \mathrm{mole}^{-1} \cdot \mathrm{cm}^{-1}$ (Fig. 2). The DHB has an absorption peak at $280 \mathrm{~nm}$ and does not absorb in the visible spectrum. Considering these facts, the present method is proposed by measuring the absorbances at 380 and $570 \mathrm{~nm}$, based on the additive property of the absorbances.

\section{Optimization of flow system}

Buffer concentration. The effect of the concentration of buffer solution was investigated from 0.100 to $1.000 \mathrm{M}$ acetate. Increasing the buffer to high concentrations increases the sensitivity but decreases the reproducibility. Concentrations below $0.100 \mathrm{M}$ are not recommended because the "buffering capacity" is low and the sample solutions are acid. The proposed system utilizes a dilute acetate solution, $0.100 \mathrm{M}$, as the carrier stream.

Effect of $p H$. The effect of $\mathrm{pH}$ was investigated by using acetate buffer $(0.100 M)$ of various $\mathrm{pH}$ values as the carrier stream. Maximum absorbance is found between $\mathrm{pH} 5.5$ and 6.0.

Flow rate. The effect of the flow-rate on the peak height was studied in the range of 2-4.5 $\mathrm{ml} / \mathrm{min}$, by injecting $200 \mu \mathrm{l}$ each of iron standard and reagent solution. The maximum signal was obtained with a flow-rate of $3.50 \mathrm{ml} / \mathrm{min}$ for each stream.

Reagent and sample volume. The influence of the sample volume on the absorbance was investigated by injecting different volumes $(50-300 \mu 1)$ of iron and titanium standard solutions into the carrier stream at the recommended flow-rate and coil length, keeping the reagent volume at $200 \mu \mathrm{l}$. The injection volume has a significant effect, yielding increased peak height and reproducibility with increasing injection volume. However, increasing the injection volume widens the sample zone and lowers the sampling rate, so that $200 \mu \mathrm{l}$ is taken as a compromise.

Length of coil. The effect of the length of the reaction coil was examined for various flowrates. Coil lengths of 50,100 and $150 \mathrm{~cm}$ were tested. Increasing the coil length lowered the peak height but improved the reproducibility. The optimum length was established as $100 \mathrm{~cm}$.

Reagent concentration. The influence of the 3,4-dihidroxybenzoic acid concentration, ranging from 0.10 to $1.00 \%$, was tested, using $200 \mu \mathrm{l}$ of reagent and of sample. A calibration graph was obtained for each concentration of reagent with iron and titanium standards,

Table 1. Sequential determination of iron and titanium in synthetic samples

\begin{tabular}{lrrrr}
\hline $\begin{array}{l}\text { Proportion } \\
\text { iron:titanium }\end{array}$ & \multicolumn{2}{c}{ Titanium $(\mu \mathrm{g} / \mathrm{ml})$} & \multicolumn{2}{c}{ Iron $(\mu \mathrm{g} / \mathrm{ml})$} \\
present & found* & present & found* \\
\hline 1.1 & 11.06 & $10.68 \pm 0.10$ & 11.27 & $10.91 \pm 0.10$ \\
2.8 & 8.05 & $8.33 \pm 0.12$ & 22.55 & $22.23 \pm 0.12$ \\
4.5 & 8.05 & $8.12 \pm 0.15$ & 36.08 & $35.91 \pm 0.15$ \\
9.0 & 4.02 & $4.09 \pm 0.10$ & 36.08 & $36.14 \pm 0.11$ \\
\hline
\end{tabular}

*95\% Confidence level. 
Table 2. Sequential determination of iron and titanium in geological matrices

\begin{tabular}{lcccc}
\hline $\begin{array}{l}\text { Standards } \\
\text { rocks }\end{array}$ & \multicolumn{2}{c}{$\begin{array}{c}\text { Titanium } \\
\text { certified }\end{array}$} & $\begin{array}{c}\left.\mathrm{TiO}_{2}\right)(\%) \\
\text { found* }\end{array}$ & \multicolumn{2}{c}{$\begin{array}{c}\text { Iron }\left(\mathrm{Fe}_{2} \mathrm{O}_{3}\right)(\%) \\
\text { certified }\end{array}$} & found* \\
\hline Bauxite NBS-USA & 2.78 & $2.86 \pm 0.10$ & 5.82 & $5.79 \pm 0.15$ \\
Clay 1-IPT-SP & 0.24 & $0.2 \pm 0.07$ & 1.93 & $1.88 \pm 0.10$ \\
Clay 2-IPT-SP & 1.04 & $0.96 \pm 0.11$ & 1.28 & $1.28 \pm 0.09$ \\
Granite-CEPED-Ba & 0.26 & $0.29 \pm 0.09$ & 1.62 & $1.63 \pm 0.11$ \\
Bauxite-CEPED-Ba & 1.19 & $1.24 \pm 0.12$ & 9.44 & $9.61 \pm 0.13$ \\
\hline
\end{tabular}

"95\% Confidence level.

Table 3. Compositions of standards analyzed

\begin{tabular}{lcccccc}
\hline Standards & $\begin{array}{c}\mathrm{Al}_{2} \mathrm{O}_{3} \\
(\%)\end{array}$ & $\begin{array}{c}\mathrm{SiO}_{2} \\
(\%)\end{array}$ & $\begin{array}{c}\mathrm{CaO} \\
(\%)\end{array}$ & $\begin{array}{c}\mathrm{MgO} \\
(\%)\end{array}$ & $\begin{array}{c}\mathrm{Na}_{2} \mathrm{O} \\
(\%)\end{array}$ & $\begin{array}{c}\mathrm{K}_{2} \mathrm{O} \\
(\%)\end{array}$ \\
\hline Bauxite NBS-USA* & 55.00 & 6.01 & 0.29 & 0.02 & 0.02 & 0.01 \\
Clay 1-IPT-SP† & 38.40 & 45.10 & 0.07 & 0.14 & 0.01 & 0.85 \\
Clay 2-IPT-SP* & 29.10 & 55.80 & 0.09 & 0.20 & 0.01 & 0.29 \\
Granite-CEPED-BA* & 15.06 & 71.80 & 1.21 & 0.50 & 3.79 & 4.78 \\
Bauxite-CEPED-Ba* & 61.47 & - & 0.04 & 0.05 & 0.06 & 0.03 \\
\hline
\end{tabular}

*Source of the certified sample.

ranging from 10.0 to $30.0 \mu \mathrm{g} / \mathrm{ml}$; all measurements were performed in triplicate. The maximum and constant slope of the calibration curve was obtained above $0.40 \%$ reagent concentration, so $0.50 \%$ concentration was selected as optimal. A study was made with $200 \mu \mathrm{l}$ of the reagent solution.

\section{Calibration graph}

A calibration graph was obtained at the optimum working conditions: reaction coil $=100$ $\mathrm{cm}$, flow-rates $3.50 \mathrm{ml} / \mathrm{min}$, reagent concentration $=0.50 \%$, volume injected $=200 \mu \mathrm{l}$ and carrier stream $=$ acetate buffer $\mathrm{pH}$ 6.0. The calibration graph was linear over the range $2-10 \mu \mathrm{g} / \mathrm{ml}$ for titanium and $10-40 \mu \mathrm{g} / \mathrm{ml}$ for iron.

\section{Effect of foreign ions}

The interference due to several anions and cations was studied in detail. In the flowinjection spectrophotometric determination of $2 \mathrm{ppm}$ of iron(III) and $1 \mathrm{ppm}$ of titanium(IV), $\mathrm{V}(\mathrm{V}), \mathrm{Mo}(\mathrm{VI}), \mathrm{Ce}(\mathrm{III}), \mathrm{Nb}(\mathrm{V})$, phosphate and tartrate ions interfered seriously. The following ions [when present in the amounts (in ppm) shown in brackets] do not interfere: $\mathrm{Mn}^{2+}(20)$, $\mathrm{Hg}^{2+}(4), \mathrm{Cu}^{2+}(10), \mathrm{Co}^{2+}(40), \mathrm{Al}^{3+}(50), \mathrm{Ni}^{2+}$ (60), $\mathrm{Ca}^{2+}(75), \mathrm{Mg}^{2+}(75), \mathrm{Pb}^{2+}(40), \mathrm{La}^{3+}(40)$, $\mathrm{Bi}^{3+}(40), \mathrm{Sr}^{2+}(40), \mathrm{SO}_{4}^{2-}(200), \mathrm{CO}_{3}^{2-}(40), \mathrm{Cl}^{-}$ (200) and $\mathrm{NO}_{3}^{-}(200)$.

However, the proposed method can be conveniently applied for the simultaneous determination of iron(III) and titanium(IV) in silicate rocks that do not contain interferents such as vanadium(V), molybdenum(IV),
cerium(III) and niobium(V), as illustrated below.

Determination of iron and titanium in synthetic samples and standard samples of rocks by flowinjection analysis

The flow-system proposed was used for the simultaneous determination of iron and titanium in several samples. The results in Table 1 show that the method can be used for determination of iron and titanium in several proportions.

The analysis of rocks revealed (Table 2) that the proposed method has satisfactory precision and can be used for determination

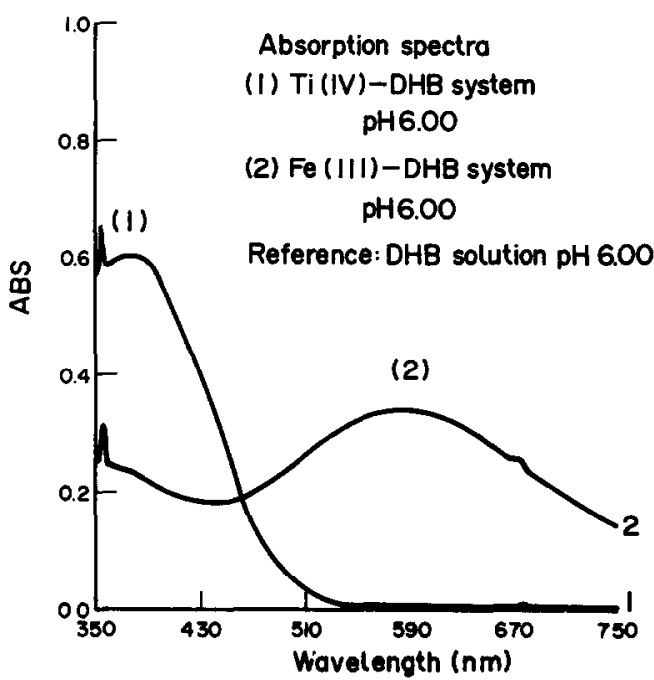

Fig. 2 Absorption spectra (1) $\mathrm{T}_{1}$ (IV)-DBH system pH 6.00 (2) Fe(III)-DHB system $\mathrm{pH} 6.00$ reference: DHB solution pH 6.00 . 
of iron and titanium in rock samples with different composition (Table 3).

DHB does not show as high a sensitivity for iron as other reagents do but it is good for titanium. However, this presents a favorable situation for the sequential determination of these elements because, in large numbers of samples, the iron level is superior to that of titanium.

\section{REFERENCES}

1. Lang's-Handbook of Chemistry McGraw-Hill Book Company.

2. K. Hgieh and S. Liang, Huaxue Xuebao, 1981, 270; Chem. Abstr., 98, 171882.

3. L. Sommer, Coll. Czech. Chem. Commun., 1963, 28, 2102.
4. T. Yamane and Y. Nozawa, Bunseki Kagaku, 1984, 33, 652; Chem. Abstr., 102, 142390a.

5. T. Yamane, Anal. Sci., 1986, 2, 191.

6. T. Kitamura and T. Yamane, Bunseki Kagaku, 1988, 37, 360; Chem. Abstr., 109, $182661 \mathrm{r}$.

7. P. Szarvas, Z. Jarabin and M. V. Braun, Proc. Conf. Appl. Phys.-Chem. Methods Chem. Anal., 1966, 3, 155; Chem. Abstr., 69, 15836a.

8. T. Matsumoto, M. Satake and T. Yonekubo, Nippon Kagaku Zasshi, 1968, 89, 944; Chem. Abstr., 70, $16827 f$.

9. E. P. Klimenko, G. N. Prokof'eva and S. Ya. Shnaiderman, Khim. Prom. Ukr., 1969, 2, 41, Chem. Abstr., 71, 9408n.

10. J. Horak, Scr. Fac. Sci. Nat. Univ. Purkynianae Brun, 1974, 4, 1; Chem. Abstr., 84, 25477h.

11. C. V. Rao, M. S. Rao and K. Srinivasulu, Indian J. Chem.,1980, 19A, 931; Chem. Abstr., 94, 244465.

12. I. M. Kolthoff and P. J. Elving, Treatise on Analytical Chemistry, Part II, Vol. 5, p. 16. Interscience, New York, 1961. 